\title{
Novel polar lipid composition of Clostridium innocuum as the basis for an assessment of its taxonomic status
}

\author{
Norah C. Johnston, ${ }^{1}$ Howard Goldfine ${ }^{1}$ and Werner Fischer ${ }^{2}$ \\ Author for correspondence: Howard Goldfine. Tel: +1 215898 6384. Fax: +1 2158989557.
}

\author{
1 Department of \\ Microbiology, University of \\ Pennsylvania, School of \\ Medicine, Philadelphia, \\ Pennsylvania 19104-6076, \\ USA \\ 2 Institut für Biochemie, \\ Friedrich-Alexander- \\ Universität, Fahrstrasse 17 \\ D-8520 Erlangen, Germany
}

\begin{abstract}
The extractable polar lipids of Clostridium innocuum have been shown to consist of glycosyldiradylglycerols, phospholipids and phosphoglycolipids. The major glycosyldiradylglycerols are $\mathrm{D}-\mathrm{GlCp}(\alpha 1-3) \mathrm{radyl}_{2} \mathrm{Gro}$ and $\mathrm{D}-\mathrm{Gal} p(\alpha 1-2) \mathrm{D}$ Glcp( $\alpha 1-3)$ radyl ${ }_{2}$ Gro. Both glycolipids have some 1-0-(alk-1-enyl)-2-0-acyl species, in addition to diacyl species. The phospholipids include bisphosphatidylglycerol (cardiolipin), lysocardiolipin and phosphatidylglycerol (PG). In addition, several novel lipids have been found, including a PG acetal of cardiolipin plasmalogen, smaller amounts of a lyso form of this lipid, a PG acetal of PG plasmalogen, and two phosphoglycolipids, which represent $65 \%$ of total polar lipids. The latter have been identified as 2'-amino-1', $3^{\prime}$ dihydroxypropane-3'-P-6-D-Galp( $\alpha 1-2) D-G \mid c p(\alpha 1-3)$ radyl ${ }_{2}$ Gro and a derivative of this lipid containing an acyl chain esterified to 0-6 of the glucopyranosyl ring. Based on rRNA sequence data, $C$. innocuum is considered to be a relative of the mycoplasmas. Its unique lipid composition permits an assessment of the taxonomic status of $C$. innocuum, since the lipid amphiphiles display marked differences from those of Acholeplasma laidlawii.
\end{abstract}

Keywords: Clostridium innocuum, polar lipids, chemotaxonomy, plasmalogen, phosphoglycolipid

\section{INTRODUCTION}

The genus Clostridium has long been recognized as one of great metabolic diversity and of considerable divergence of its DNA guanine plus cytosine $(\mathrm{G}+\mathrm{C})$ content (Cato $e t$ al., 1986). The rRNA studies of Johnson \& Francis (1975) led to a division of this genus into four main groupings: homology groups I and II, which contained species with $22-29 \mathrm{~mol} \% \mathrm{G}+\mathrm{C}$; group III, containing species with $26-33 \mathrm{~mol} \% \mathrm{G}+\mathrm{C}$, which did not belong in the other groups; and group IV, containing species with 41$45 \mathrm{~mol} \% \mathrm{G}+\mathrm{C}$. These divisions were further supported by the work of Stackebrandt \& Woese (1981) and their colleagues, who catalogued the 16S rRNA of a wide variety of bacteria. Their work led to the following conclusion: 'The low G + C Gram-positive bacteria are seen to be structured largely in terms of the clostridia. Far from being simply a genus, Clostridium appears to be a major phylogenetic unit, deeper (more ancient) even than the entire group of high G + C Gram-positive bacteria.' They also noted that the true mycoplasmas, i.e. the genera

Abbreviations: 1D, one-dimensional ; 2D, two-dimensional; PG, phosphatidylglycerol; CL, cardiolipin (bisphosphatidylglycerol).
Mycoplasma and Acholeplasma, appear to be offshoots of the clostridia. Two clostridial species, $C$. ramosum and $C$. innocuum, were considered to be specific relatives of the mycoplasmas. A separate examination of clostridial phylogenetic groupings was based on the structure of $5 S$ rRNA. A limited group of clostridia was studied, and they were separated into three clusters. Again the relationship of $C$. innocuum to Acboleplasma was noted (Dams et al., 1987).

The lipids of clostridia, with the exception of the apolar chains, have not been extensively examined. Most of the available information concerns a limited group of saccharolytic, butyric-acid-producing species including: Clostridium beijerinckii ATCC 6015, (formerly C. butyricum), C. butyricum, C. acetobutylicum and C. saccharoperbutylacetonicum (see Goldfine, 1993; O'Leary \& Wilkinson, 1988 , and references therein). In addition, limited information is available on $C$. pasteurianum and $C$. thermocellum (Goldfine, 1993; O'Leary \& Wilkinson, 1988). We have begun to examine the polar lipids and glycoconjugates of clostridia with a view to testing the value of lipid compositional data in the chemotaxonomy of this diverse group of organisms. It has been apparent for at 
least two decades that the study of lipid composition provides significant data for bacterial taxonomy. Lipids show group-to-group and even species-to-species variations (Lechevalier \& Lechevalier, 1988). In view of the suggested phylogenetic relationship between $C$. innocuum and Mycoplasma and Acholeplasma, we have begun with a study of the lipids of $C$. innocuum.

\section{METHODS}

Materials. Reinforced clostridial medium (RCM) was obtained from Unipath. Glass-distilled solvents, silica gel 100 and precoated TLC plates were from Merck. DEAE-cellulose was obtained from Whatman or Merck. Lipid standards were purchased from Sigma. D-Glc $p(\alpha 1-3)$ acyl $_{2}$ Gro, D-Gal $p(\alpha 1-2)$ DGlc $p(\alpha 1-3)$ acyl $_{2}$ Gro and D-Gal $p(\alpha 1-2)$, acyl-6-D-Glc $p(\alpha 1-$ $3)$ acyl $_{2}$ Gro were available from previous preparations (Nakano $\&$ Fischer, 1977). The glycerol assay kit was purchased from Boehringer Mannheim; 'Purpald' was from Aldrich. Membrane preparations isolated from Haemophilus parainfuenzae were generously provided by Fang-Hua Lee.

Growth of cells, and extraction and separation of lipids. $C$. innocuum A TCC 14501 was grown on RCM in anaerobic culture overnight at $37^{\circ} \mathrm{C}$ to a Klett $_{600}$ reading $>200$ and $\mathrm{pH}$ approximately $5 \cdot 5$. The cells were harvested using a Millipore Pellicon cassette concentrator and the wet cell paste was lyophilized. For glycolipid separation, freeze-dried cells were suspended in $0.1 \mathrm{M}$ sodium acetate buffer $\mathrm{pH} 4.7(1 \mathrm{~g}$ in $10 \mathrm{ml})$ and disintegrated with glass beads in a Braun disintegrator as described previously by Fischer et al. (1983). Lipids were extracted by a modified Bligh-Dyer procedure (Kates, 1986).

For phospholipid separation the lyophilized cells were suspended in water $(1: 4, \mathrm{w} / \mathrm{v})$ and extracted three times with 6 vols chloroform/methanol $(1: 1, \mathrm{v} / \mathrm{v})$, the extract was evaporated almost to dryness, and nonlipid contaminants were removed by partition against $0.05 \mathrm{M} \mathrm{NaCl}$. Phospholipids were separated from neutral lipids and glycosyldiradylglycerols by acetone precipitation, followed by chromatography on DEAE-cellulose acetate (Johnston \& Goldfine, 1988). Purification of individual lipids was by preparative TLC.

Thin-layer chromatography. The following TLC solvents (by vol.) were used on silica gel plates except where noted: A, chloroform/methanol/water, 65:25:4; $\mathrm{B}$, chloroform/ methanol $/ 25 \%$ ammonia/water, $60: 30: 3: 3$; $C$ and $\mathrm{C}^{\prime}$, chloroform/acetone/methanol/acetic acid/water, $5: 2: 1: 1: 0.5$ or $8: 2: 1: 1: 0 \cdot 4$; D, chloroform/methanol, $98: 2$; E, chloroform/ methanol $/ 7 \mathrm{M}$ ammonium hydroxide, $60: 35: 5$; F, chloroform/methanol/acetic acid/water, $8: 1 \cdot 8: 1 \cdot 2: 0 \cdot 5 ; \mathrm{G}$, chloroform/methanol/acetic acid, $65: 25: 8 ; \mathrm{H}$, light petroleum (b.p. $30-60^{\circ} \mathrm{C}$ )/diethyl ether/acetic acid, $70: 30: 1$; I, on cellulose TLC plates, first dimension: $3.8 \mathrm{mM}$ EDTA, $0.7 \mathrm{M}$ ammonium bicarbonate in $90 \mathrm{mM}$ ammonium hydroxide $/ 67 \%$ ethanol; second dimension: isobutyric acid/water/conc. ammonia, 66:33:1 (Short et al., 1969); J, on cellulose TLC plates, ethanol $/ 1 \mathrm{M}$ ammonium acetate, $\mathrm{pH} 7 \cdot 5,6 \cdot 5: 3 \cdot 5 ; \mathrm{K}$, propan-1ol/ethyl acetate/water, $7: 2: 2$.

Detection reagents were as follows: phospholipids, molybdenum blue spray reagent (Sigma); glycolipids and phosphoglycolipids, $\alpha$-naphthol (Vioque, 1984); neutral lipids, Rhodamine B; and for glycerol phosphate esters, the molybdate spray of Hanes and Isherwood (Dawson, 1967).

Chemical assays. Organic phosphate was measured by the method of Bartlett (1959), vinyl ethers by iodine uptake (Gottfried \& Rapport, 1962) and by the p-nitrophenylhydrazone assay (Wittenberg et al., 1956), and acyl esters by the hydroxamate assay (Kates, 1986). Glycerol was assayed enzymically (Nägele et al., 1985; Eggstein \& Kuhlmann, 1974), and sugars by an anthrone procedure (Yamamoto \& Rouser, 1970). Fatty acids (Behr et al., 1992), D-galactose (Beutler, 1984) and Dglucose (Kunst et al., 1984), were assayed as described in the respective references. Protein was measured by the Lowry procedure.

Glycolipid analysis. For compositional analysis, glycolipids were hydrolysed in $2 \mathrm{M} \mathrm{HCl}\left(100^{\circ} \mathrm{C}, 2.5 \mathrm{~h}\right)$, and after cooling, fatty acids were extracted with light petroleum/chloroform $(4: 1, v / v)$. Mild deacylation was performed as described by Kates (1986). Glycosylglycerols were methylated by the procedure of Ciucanu \& Kerek (1984). The methylation products were hydrolysed in $2 \mathrm{M} \mathrm{HCl}\left(100^{\circ} \mathrm{C}, 2.5 \mathrm{~h}\right)$. After drying in vacuo, the partially methylated monosaccharides were reduced with $\mathrm{NaB}^{2} \mathrm{H}_{4}$, peracetylated and analysed by GLC-MS (Lindberg, 1972). For treatment with $\mathrm{CrO}_{3}$ of peracetylated glycosylglycerols, the procedure of Laine \& Renkonen (1975) was followed except that resistant monosaccharide constituents were released by hydrolysis with $2 \mathrm{M} \mathrm{HCl}\left(100^{\circ} \mathrm{C}, 2 \cdot 5 \mathrm{~h}\right)$.

GLC and GLC-MS were carried out as described previously (Behr et al., 1992). Fatty acids and fatty aldehydes were released by acid hydrolysis $\left(2 \mathrm{M} \mathrm{HCl}, 100^{\circ} \mathrm{C}, 2 \cdot 5 \mathrm{~h}\right)$, extracted with light petroleum/chloroform $(3: 1, \mathrm{v} / \mathrm{v})$ and methylated with $10 \%$ (w/v) methanolic $\mathrm{BCl}_{3}\left(80^{\circ} \mathrm{C}, 10 \mathrm{~min}\right)$. Unsaturated fatty acid methyl esters were identified on GLC by co-chromatography with standards (methyl esters of cis-9 or trans-9-hexadecenoate, cis-9, trans-9-, cis-11-, and trans-11-octadecenoate) on two fused silica capillary columns, HP-5 (5\% diphenyl-/95\% dimethylpolysiloxane, $25 \mathrm{~m}$, internal diameter $0.32 \mathrm{~mm}$, film thickness $0.33 \mu \mathrm{m})$ and DB $225 \quad(50 \%$ cyanopropylmethyl $/ 50 \%$ methylphenyl-polysiloxane, $30 \mathrm{~m}$, internal diameter $0.24 \mathrm{~mm}$, film thickness $0 \cdot 25 \mu \mathrm{m}$ ), which were run isothermally at 180 and $150{ }^{\circ} \mathrm{C}$, respectively. cis-Isomers emerged ahead of the respective trans-isomers from the apolar column (HP-5); on the polar column (DB 225) the order was reversed.

Glycerophospholipid analysis. The lipid class composition of the acetone-insoluble lipids was determined by triplicate twodimensional (2D) TLC in solvent system $\mathrm{E}$ followed by solvent system $F$ on $10 \times 10 \mathrm{~cm}$ silica gel 60 plates. The lipids were stained with iodine, scraped into acid-washed tubes and digested for phosphate analysis (Goldfine et al., 1993). Minor lipids were combined as indicated. Purified phospholipids $(0 \cdot 5-2 \cdot 0 \mathrm{mg})$ were hydrolysed in $1 \mathrm{ml}$ chloroform/methanol $(1: 1, \mathrm{v} / \mathrm{v})$ plus $0.5 \mathrm{ml} 2 \mathrm{M} \mathrm{HCl}$. The mixture was vortex mixed and incubated at $55^{\circ} \mathrm{C}$ for $3 \mathrm{~min}$ (Johnston \& Goldfine, 1988), cooled on ice and neutralized by addition of approximately $0.7 \mathrm{ml} 1.5 \mathrm{M}$ ammonium hydroxide. After extraction by the method of Bligh \& Dyer (1959), the acid-stable lipids were deacylated by alkaline methanolysis (Kates, 1986).

NMR spectra were obtained with a Brucker AM-500 spectrometer. Samples were dissolved in deuterated chloroform/ methanol $(2: 1, \mathrm{v} / \mathrm{v})$ and spectra were recorded as previously described (Johnston \& Goldfine, 1988).

\section{RESULTS}

\section{Lipid content}

One gram of lyophilized cells contained $250 \mathrm{mg}$ protein and $37 \mathrm{mg}$ total lipid. The lipid consisted of phospholipids plus phosphoglycolipids $(0.66 \mu \mathrm{mol}$ lipid $\mathrm{P}$ per mg total lipid) and glycolipids plus phosphoglycolipids $(1.5 \mu \mathrm{mol}$ lipid hexose per $\mathrm{mg}$ total lipid). The vinyl ether content 
Table 1. Apolar chain compositions of the total lipids and of glycolipids I and II of C. innocuum

The data, in mol $\%$, represent the means of two experiments with a reproducibility of $\pm 5 \%$ or better. ND, Not detected (see text).

\begin{tabular}{|lrcc|}
\hline Component & $\begin{array}{c}\text { Total } \\
\text { lipid }\end{array}$ & $\begin{array}{c}\text { Glycolipid } \\
\text { I }\end{array}$ & $\begin{array}{c}\text { Glycolipid } \\
\text { II }\end{array}$ \\
\hline Dodecanoate & $3 \cdot 2$ & $4 \cdot 9$ & $5 \cdot 3$ \\
Tetradecenoate* & $1 \cdot 6$ & $1 \cdot 5$ & $2 \cdot 1$ \\
Tetradecanoate & $9 \cdot 9$ & $10 \cdot 2$ & $10 \cdot 5$ \\
Hexadecenoate* & $5 \cdot 2$ & $6 \cdot 0$ & $4 \cdot 7$ \\
cis-9-Hexadecenoate & $7 \cdot 9$ & $9 \cdot 6$ & $10 \cdot 9$ \\
Hexadecanoate & $26 \cdot 0$ & $19 \cdot 5$ & $26 \cdot 1$ \\
cis-9-Octadecenoate & $13 \cdot 1$ & $25 \cdot 2$ & $19 \cdot 7$ \\
cis-11-Octadecenoate & $3 \cdot 7$ & $6 \cdot 9$ & $6 \cdot 7$ \\
Octadecanoate & $14 \cdot 3$ & $16 \cdot 2$ & $14 \cdot 0$ \\
Hexadecanal & $9 \cdot 2$ & ND & ND \\
Octadecanal & $5 \cdot 9$ & ND & ND \\
\hline
\end{tabular}

* Not further characterized.

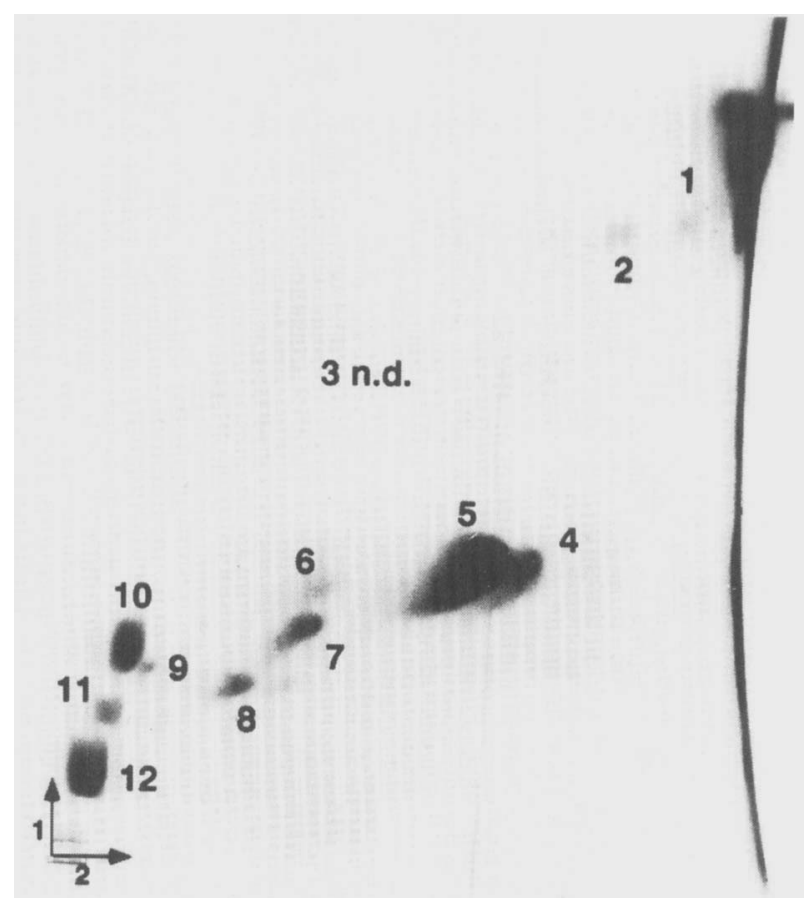

Fig. 1. 2D TLC of the polar lipids of $C$. innocuum. The solvent for the first dimension was solvent system $A$ and that for the second dimension was a modified form of solvent system $F$ with chloroform/methanol/acetic acid/water $(80: 14: 10: 3$, by vol.). The lipids were stained by treatment with phosphomolybdic acid and charring. The directions of chromatography are indicated by arrows. Numbering of the compounds is according to Table 2. Compound 3 (n.d.) was not detected in the chromatogram shown, but could be seen when more sample was applied.

was $0 \cdot 2 \mu \mathrm{mol} \mathrm{mg}{ }^{-1}$. The fatty acyl and acid-labile ether chain composition is given in Table 1. Fig. 1 shows a chromatogram of the polar lipids. Relative abundances
Table 2. Membrane polar lipid composition of $C$. innocuum

\begin{tabular}{|c|c|c|c|}
\hline No.* & Lipid & $\begin{array}{l}\text { Percentage } \\
\text { of total } \\
\text { lipid Pf }\end{array}$ & Mol \% ‡ \\
\hline 1 & Glycolipid I & & $5 \cdot 1$ \\
\hline 2 & Glycolipid & & \\
\hline 3 & Glycolipid II & & ND \\
\hline 4 & PG acetal of CL plasmalogen & $5 \cdot 6 \pm 0 \cdot 1$ & $2 \cdot 4$ \\
\hline 5 & $\begin{array}{l}\text { Biphosphatidylglycerol } \\
\text { (cardiolipin) }\end{array}$ & $26 \cdot 1 \pm 1 \cdot 9$ & $16 \cdot 3$ \\
\hline 6 & Phosphatidylglycerol & $1 \cdot 0 \pm 0.5$ & $1 \cdot 3$ \\
\hline 7 & $\begin{array}{l}\text { Lyso form of PG acetal of CL } \\
\text { plasmalogen and PG acetal of } \\
\text { plasmenylglycerol }\end{array}$ & $2 \cdot 6 \pm 0 \cdot 6$ & $1 \cdot 2$ \\
\hline 8 & Lysocardiolipin & $2 \cdot 8 \pm 0 \cdot 3$ & 1.9 \\
\hline 9 & Phosphoglycolipid & 0.9 & $1 \cdot 1$ \\
\hline 10 & Phosphoglycolipid III & $11 \cdot 9 \pm 4 \cdot 3$ & $14 \cdot 8$ \\
\hline 11 & Phosphoglycolipid II & $3 \cdot 6 \pm 0 \cdot 3$ & $4 \cdot 4$ \\
\hline 12 & Phosphoglycolipid I & $41 \cdot 2 \pm 3 \cdot 4$ & $51 \cdot 3$ \\
\hline
\end{tabular}

* Refers to Fig. 1.

tWhere errors (SEM) of the mean are given, these data represent the means of separate determinations carried out in Erlangen and Philadelphia.

$\ddagger$ ND, Not determined.

and identifications of the individual components are summarized in Table 2. There were three glycolipids, five phospholipids, and four phosphoglycolipids. The latter were identified by their staining with 1 -naphthol $/ \mathrm{H}_{2} \mathrm{SO}_{4}$ and a molybdenum blue spray reagent. The most abundant component was phosphoglycolipid I $(51 \mathrm{~mol} \%)$, followed by bisphosphatidylglycerol $(16 \mathrm{~mol} \%)$. The comparatively large spot of the latter on TLC (Fig. 1) was probably caused by microheterogeneity owing to the presence of four hydrocarbon chains.

\section{Glyceroglycolipids}

When the crude lipid extract was chromatographed on a column of DEAE-cellulose, as described previously (Fischer, 1977), two glycolipids (I, II) emerged from the column on elution with chloroform/methanol $97: 3$ and 9:1 (v/v), respectively. On TLC, glycolipid I (Fig. 1, spot 1) co-chromatographed with $\mathrm{D}$-Glc $p(\alpha 1-3)$ acyl. Gro in solvents $\mathrm{A}, \mathrm{B}$, and $\mathrm{C}^{\prime}$. Chromatography in solvent $\mathrm{C}^{\prime}$ excluded the presence of D-Gal $p(\alpha 1-2)$, acyl-6-D-GIc $p(\alpha 1$ 3) $\operatorname{acyl}_{2}$ Gro (Fischer, 1984). Glycolipid II (Fig. 1, spot 3) co-chromatographed with D-Gal $p(\alpha 1-2) \mathrm{D}-\mathrm{Glc} p(\alpha 1-$ 3 ) acyl $_{2}$ Gro in solvents A-C. On analysis glycolipid I gave D-glucose, glycerol, and fatty acids in molar ratios of $1: 1: 2$. Glycolipid II contained in addition $D$-galactose in equimolar ratio to glucose and glycerol. The fatty acid composition of each glycolipid is listed in Table 1. Longchain aldehydes were not recovered from the acid hydrolysate. It should be noted, however, that 2D TLC in solvent $\mathrm{E}$ with acid hydrolysis (Viswanathan et al., 1968) 
showed that fractions of these glycolipids were hydrolysed releasing aldehydes, which were detected at the solvent front by 'Purpald' reagent (Rahn \& Schlenk, 1973). Glycosyldiacylglycerol was not hydrolysed by this method. Aldehydes can be lost by condensation with available hydroxyl groups on acid hydrolysis (Johnston \& Goldfine, 1988). Analysis of glycolipid I gave glycerol:ester: vinyl ether molar ratios of $1: 1 \cdot 8: 0 \cdot 19$. Proton NMR of glycolipid I showed a multiplet at 5.8 -5.9 p.p.m., which is characteristic of the vinyl ether grouping.

On methylation analysis (Ciucanu \& Kerek, 1984), glycolipid I yielded 2,3,4,6-tetra- $O$-methylglucose and glycolipid II gave approximately equimolar amounts of 2,3,4,6-tetra-O-methylgalactose and 3,4,6-tri-O-methylglucose, which were identified as alditol acetates by GLCMS (Lindberg, 1972). Both glycolipids survived treatment with $\mathrm{CrO}_{3}$ (Laine \& Renkonen, 1975) as was shown by TLC in solvent $\mathrm{D}$ and by the unchanged molar ratios of the constituent sugat components to glycerol. Since all sugars were in the pyranose form, the resistance to oxidation with $\mathrm{CrO}_{3}$ indicates the $\alpha$-configuration. Taking further into account that glyceroglycolipids are biosynthetically derived from 1,2-di-O-acylglycerol, we propose for glycolipid I the structure D-Glc $p(\alpha 1-3)$ radyl $_{2}$ Gro, and for glycolipid II, D-Gal $p(\alpha 1-2) \mathrm{D}-\mathrm{Glc} p(\alpha 1-$ 3) $\mathrm{radyl}_{2}$ Gro.

\section{Glycerophospholipids}

Bisphosphatidylglycerol (cardiolipin). Cardiolipin (CL; Fig. 1, spot 5) was identified as the most abundant phospholipid, representing approximately $25 \%$ of total lipid P. It was eluted from DEAE-cellulose acetate by $0.2 \%$ ammonium acetate in chloroform/methanol $(2: 1$, $\mathrm{v} / \mathrm{v}$ ), and purified by preparative TLC in solvent system G. 1D and 2D TLC with authentic samples gave inconsistent results, presumably due to differences in lipid aliphatic chain compositions and countercations between the bacterial lipids and standards. The product of successive mild acid and mild alkaline hydrolysis cochromatographed with GroPGroPGro in solvent systems $\mathrm{I}, \mathrm{J}$ and K. Acetolysis (Coulon-Morelec et al., 1960) gave a water-soluble product which co-chromatographed with authentic glycerol 1,3-bisphosphate in solvent system J, and a lipid product consisting of mono- and diacylglycerol, which were identified by TLC with authentic standards in solvent system $\mathrm{H}$. The presence of monoacylglycerol was consistent with significant amounts of acid-labile lipid (plasmalogens). Analysis of the intact lipid gave a phosphorus:(ester + vinyl ether): glycerol ratio of $2: 4: 3$. Of the aliphatic chains, $16 \%$ were linked by a vinyl ether bond. The parent lipid was also hydrolysed with a CL-specific phospholipase $\mathrm{D}$ in the membrane fraction of Haemophilus parainfluenzae (Ono \& White, 1970). The products of hydrolysis were identified as phosphatidylglycerol (PG) and phosphatidic acid by 2D TLC in solvent system E followed by F. Proton NMR of the parent lipid showed the presence of vinyl ethers and a secondary hydroxyl group, but no primary hydroxyl in the polar head group.
Lysocardiolipin. Lysocardiolipin (Fig. 1, spot 8) was a minor component of freshly extracted $C$. innocuum lipids which increased upon storage of lipid extracts. It cochromatographed with PG in neutral and acidic TLC systems but could be separated from PG in solvent system E. ${ }^{32}$ P-labelled lysocardiolipin co-chromatographed with lysocardiolipin prepared from $C$. butyricum CL (Goldfine et al., 1982) by acid hydrolysis. Deacylated lysocardiolipin chromatographed as GroPGroPGro on 2D TLC in solvent system I. The water-soluble product of acetolysis was a mixture of glycerol 1,3-bisphosphate, glycerol 1phosphate, and a presumptive cyclic phosphate. An authentic sample of lysocardiolipin gave the same products. Acid hydrolysis of the presumptive cyclic phosphate produced a mixture of glycerol 1,3- and 1,2bisphosphates.

PG. This lipid (Fig. 1, spot 6) comprised $1 \%$ of the total lipid P. 2D TLC in solvent systems $E$ followed by F, or $E$ followed by $G$, showed a minor spot corresponding in mobility to authentic PG. A fraction eluted from a preparative silicic acid column by chloroform/methanol $(4: 1, \mathrm{v} / \mathrm{v})$ contained a phospholipid which cochromatographed upon 2D TLC in solvent systems E followed by $\mathrm{F}$ with $\left[{ }^{32} \mathrm{P}\right] \mathrm{PG}$ isolated from labelled Escherichia coli phospholipids (Goldfine et al., 1993).

PG acetal of the plasmalogen form of CL. This lipid (Fig. 1, spot 4), which represented $5.6 \%$ of total lipid P, has not been previously identified and a complete description of its structural characterization will be published elsewhere. The structure was established by chemical analyses, analysis of the acid and alkaline hydrolysis products of the native and hydrogenated compounds, the products of treatment with a cardiolipinspecific phospholipase $\mathrm{D}$, and $1 \mathrm{D}$ and $2 \mathrm{D}{ }^{1} \mathrm{H}-\mathrm{NMR}$. It is related to the previously characterized PG acetal of the plasmalogen form of phosphatidylethanolamine (Johnston \& Goldfine, 1988). A lyso form of this lipid is also present in which one aliphatic chain is absent. It represents 2 to $4 \%$ of total lipid P (Fig. 1, spot 7).

PG acetal of the plasmalogen form of PG. This phospholipid (Fig. 1, spot 7) represents $<1 \%$ of total lipid P. The structure of this compound is based on an analysis of its acid hydrolysis products. A description of its characterization will be published elsewhere.

\section{Phosphoglycolipids}

A unique feature of the lipid pattern is the presence of two major and two minor phosphoglycolipids, which together represent $55-60 \%$ of the lipid phosphorus. Analysis of the two major components (Fig. 1, spots 10 and 12) revealed that they are derived from the membrane glycolipid $\quad \mathrm{D}-\mathrm{Gal} p(\alpha 1-2) \mathrm{D}-\mathrm{Glc} p(\alpha 1-3)$ radyl ${ }_{2}$ Gro. Both compounds carry a 2-amino-1(3)-dihydroxypropane 3(1)phosphate residue attached to O-6 of the galactopyranosyl residue. The less polar component (Fig. 1, spot $10)$ is esterified with a third fatty acid at O-6 of the glucopyranosyl residue. The complete structures have been established by chemical analyses, NMR studies $\left({ }^{1} \mathrm{H}\right.$, ${ }^{13} \mathrm{C}, 1 \mathrm{D}$ and $\left.2 \mathrm{D}\right)$ and by fast atom bombardment mass 
Table 3. Comparison of lipid amphiphile composition of C. innocuum and Acholeplasma laidlawii

\begin{tabular}{|c|c|c|}
\hline C. innocuum & A. laidlawii & Reference(s) \\
\hline D-Glc $p(\alpha 1-3)$ radyl $_{2}$ Gro* $^{*}$ & D-Glc $p(\alpha 1-3)$ acyl $_{2}$ Gro & $\begin{array}{l}\text { Shaw et al. (1968); } \\
\text { Wieslander \& Rilfors (1977) }\end{array}$ \\
\hline D-Gal $p(\alpha 1-2)$ D-Glc $p(\alpha 1-3)$ radyl $_{2}$ Gro* & D-Glc $p(\alpha 1-2) \mathrm{D}-\mathrm{Glc} p(\alpha 1-3) \mathrm{acyl}_{2} \mathrm{Gro}$ & $\begin{array}{l}\text { Shaw et al. (1968); } \\
\text { Wieslander \& Rilfors (1977) }\end{array}$ \\
\hline Bisphosphatidylglycerol (cardiolipin) & Cardiolipin & Smith (1972) \\
\hline Phosphatidylglycerol & Phosphatidylglycerol & $\begin{array}{l}\text { Smith (1972); Wieslander \& } \\
\text { Rilfors (1977) }\end{array}$ \\
\hline $\begin{array}{l}2^{\prime} \text {-Amino-1', } 3^{\prime} \text {-dihydroxypropane- } 3^{\prime}-P-6- \\
\text { D-Gal } p(\alpha 1-2) \text { D-Glc } p(\alpha 1-3) \text { radyl }_{2} \mathrm{Gro}^{*}\end{array}$ & $\begin{array}{l}s n-G r o-3-P-6[\mathrm{D}-\mathrm{Glc} p(\alpha 1-2) \\
\text { D-Glc } p(\alpha 1-3)]]_{\text {acyl }} \text { Gro }\end{array}$ & $\begin{array}{l}\text { Wieslander \& Rilfors (1977); } \\
\text { Shaw et al. (1972) }\end{array}$ \\
\hline Poly(glycosylglycerophospho)-lipoteichoic acid $\dagger$ & $\begin{array}{l}\text { Lipoglycan (Glc, Man, } \\
\text { deoxyhexosamine, GlcN, GalN) }\end{array}$ & Smith (1977) \\
\hline
\end{tabular}

*Contains some 1-O-(alk-1-enyl)-2-O-acyl species. †W. Fischer, unpublished.

spectroscopy. These data will be described in detail elsewhere.

\section{DISCUSSION}

Examination of the polar lipids of $C$. innocuum has revealed several unusual features including: $(a)$ the presence of novel PG acetals of plasmalogens, $(b)$ the absence of common amino lipids, and $(c)$ a high content of phosphoglycolipids. The presence of ether lipids in clostridia is well known (Goldfine \& Hagen, 1972; Goldfine, 1993). The major types have been previously characterized as plasmalogens or glycerol acetals of plasmalogens. In this study we report that the predominant ether lipids of $C$. innocuum consist of plasmalogens and PG acetals of plasmalogens, a recently characterized class of ether lipids in which the primary hydroxyl group of PG forms an acetal with the C- 1 of the $s n-1$ ether chain of a plasmalogen. The first member of this class of lipids was found in $C$. butyricum and shown to be a PG acetal of plasmenylethanolamine (Johnston \& Goldfine, 1988). Subsequent studies have examined the precursor-product relationships of this lipid with the corresponding plasmalogen (MacDonald \& Goldfine, 1990).

Aminophospholipids such as phosphatidylethanolamine, phosphatidyl- $N$-monomethylethanolamine, and their respective plasmalogens, are major phospholipids of the saccharolytic, butyric-acid-producing clostridia including C. butyricum, C. beijerinckii, C. acetobutylicum, and related species (Johnston \& Goldfine, 1983). There is a division of Gram-positive bacteria between the aminolipid-containing, spore-forming genus Bacillus and the nonsporeforming genera, Streptococcus and Lactobacillus (Goldfine, 1982) which mirrors differences in their $16 \mathrm{~S}$ rRNA sequences. These sequences have been used to construct a bacterial phylogeny, in which a division of the Gram-positive tree into two major trunks was proposed (Stackebrandt \& Woese, 1981). One trunk includes the high $\mathrm{G}+\mathrm{C}(\geqslant 55 \mathrm{~mol} \%)$ 'actinomyces' group, whose members have a distinctive lipid composition (Goldfine, $1982)$, and another major trunk, the low $G+C$ ( $\leqslant 50 \mathrm{~mol} \%$ ) 'clostridia', which diverge to form bacillus, lactobacillus and streptococcus groups, and four groups of clostridia.

In this phylogeny, which is supported by $5 \mathrm{~S}$ rRNA sequence analyses (Dams et al., 1987; Rogers et al., 1985), Mycoplasma and Acholeplasma are considered to be offshoots of the low $\mathrm{G}+\mathrm{C}$ Gram-positive branch, and two clostridia, $C$. innocuum and $C$. ramosum, are thought to be specific relatives of the mycoplasmas (Mollicutes). Table 3 compares some of the major features of the polar lipids of A. laidlawii, as an example of Mollicutes, with those we have found in C. innocuum. In common with other Grampositive bacteria both species have CI, PG, glycosyldiradylglycerols and phosphoglycolipids. A. laidlawii contains in addition D- and L-alanyl PG (Koostra \& Smith, 1969) and phosphatidyldihexosyldiacylglycerol (Smith, 1972). The monoglycosyldiacylglycerol in both organisms is $\mathrm{D}-\mathrm{Glc} p(\alpha 1-3) \mathrm{radyl}_{2}$ Gro. In $A$. laidlawii the glycolipids are diacyl, while those in $C$. innocuum have some vinylether-linked chains. The diglycosyldiacylglycerols differ in having as the terminal sugar $\alpha$-D-galactose in $C$. innocuum and $\alpha$-D-glucose in $A$. laidlawii. D-Gal $p(\alpha 1-2) \mathrm{D}-\mathrm{Glc} p(\alpha 1-$ $3)$ acyl $_{2}$ Gro has previously been found in other Grampositive bacteria such as lactobacilli and Streptococcus pneumoniae (Kates, 1990). A major component of the polar lipids of $C$. innocuum is a novel derivative of the diglycosyldiradylglycerol in which 2-amino-1,3-dihydroxypropane 3-phosphate is substituted on O-6 of the terminal galactose. This structure differs from the $s n$ glycero-3-phosphoglycolipid found in $A$. laidlawii. It should be noted here that these 'aminoglycerophosphoglycolipids', in contrast to the glycerophosphoglycolipids of other Gram-positive bacteria (Fischer, 1990), are not related to lipoteichoic acid and therefore serve exclusively as membrane components. A further difference between $C$. innocuum and $A$. laidlawii is the presence of a poly(glycosylglycerophospho)-lipoteichoic acid in the former and a lipoglycan in the latter species (Table 3).

Based on lipid amphiphile composition, it appears that $C$. innocuum is no more closely related to Mollicutes than it is to other Gram-positive bacteria such as Streptococcus and Lactobacillus. It is of interest that a more recent proposal 
for a hierarchical structure for the Gram-positive bacteria groups $C$. innocuum and C. ramosum in the same family with Lactobacillus catenaforme, Erysipelothrix and Streptococcus pleomorphus (Cato \& Stackebrandt, 1989). There is little detailed information on the lipid amphiphiles of these non-clostridial species (O'Leary \& Wilkinson, 1988).

Much more work needs to be done on the lipids of clostridia before a coherent chemotaxonomic picture emerges. This ancient group of bacteria will probably be divided into different taxa as more information on macromolecular structures is obtained (Cato \& Stackebrandt, 1989). Recent work has shown the utility of analysis of the apolar chains in identification of clostridia (Ghanem et al., 1991), but with the exception of five species of Clostridium, definitive data on the polar lipids is not available (O'Leary \& Wilkinson, 1988). Given the wide variation in phospholipid and glycoconjugate structure and composition among Gram-positive species, the value of information on clostridial complex lipids for chemotaxonomy is evident.

\section{ACKNOWLEDGEMENTS}

This work was supported in part by a National Institutes of Health Research Grant AI-08903 (to H. G.) and by a grant of the Deutsche Forschungsgemeinschaft, Fi 218/4-8 (to W.F.). The reliable technical assistance of Edeltraud Ebnet is gratefully acknowledged by W.F. We would like to express our appreciation to Fang-Hua Lee for the gift of $H$. parainfluenzae membranes.

\section{REFERENCES}

Bartlett, G. R. (1959). Phosphorus assay in column chromatography. J Biol Chem 234, 466-468.

Behr, T., Fischer, W., Peter-Katalinic, J. \& Egge, H. (1992). The structure of pneumococcal 'lipoteichoic acid'. Improved preparation, chemical and mass spectrometric studies. Eur J Biochem 207, 1063-1075.

Beutler, H. O. (1984). Lactose and galactose. In Methods of Envymatic Analysis, vol. VI, pp. 104-112. Edited by H. U. Bergmeyer, J. Bergmeyer \& M. Grassl. Weinheim/Deerfield Beach, FL/Basel: Verlag Chemie.

Bligh, E. G. \& Dyer, W. J. (1959). A rapid method of total lipid extraction and purification. Can J Biochem Physiol 37, 911-917.

Cato, E. P. \& Stackebrandt, E. (1989). Taxonomy and phylogeny. In Clostridia, pp. 1-26. Edited by N. P. Minton \& D. J. Clarke. New York: Plenum Press.

Cato, E. P., George, W. L. \& Finegold, S. M. (1986). Genus Clostridium Prazmowski 1880,23 ${ }^{\mathrm{AL}}$. In Bergey's Manual of Systematic Bacteriology, vol. 2, pp. 1141-1200. Edited by P. H. A. Sneath, N. S. Mair, M. E. Sharpe \& J. G. Holt. Baltimore: Williams \& Wilkins.

Ciucanu, I. \& Kerek, F. (1984). A simple and rapid method for the permethylation of carbohydrates. Carbobydr Res 131, 209-217.

Coulon-Morelec, M. J., Faure, M. \& Marechal, J. (1960). Etude du mécanisme de la libération des diglycérides des phosphatides sous l'action de l'acide acétique chaud. Bull Soc Cbim Biol 42, 867-876.

Dams, E., Huysmans, E., Vandenberghe, A. \& DeWacheter, R. (1987). Structure of clostridial $5 S$ ribosomal RNAs and bacterial evolution. Syst Appl Microbiol 9, 54-61.

Dawson, R. M. C. (1967). Analysis of phosphatides and glycolipids by chromatography of their partial hydrolysis or alcoholysi products. In Lipid Chromatographic Analysis, pp. 163-189. Edited b. G. V. Marinetti. New York: Marcel Dekker.

Eggstein, M. \& Kuhlmann, E. (1974). Triglycerides and glycerol Determination after alkaline hydrolysis. In Methoden der En₹y matischen Analyse, vol. 4, pp. 1825-1831. Edited by H. U Bergmeyer. New York \& London: Academic Press.

Fischer, W. (1977). The polar lipids of group B streptococci. I Glucosylated diphosphatidylglycerol, a novel glycophospholipid Biocbim Biophys Acta 487, 74-88.

Fischer, W. (1984). Glycoglycerolipids. In Handbook of Chromat ograpby, Lipids, vol. I, pp. 555-587. Edited by H. K. Mangold, Boc: Raton, FL: CRC Press.

Fischer, W. (1990). Bacterial phosphoglycolipids and lipoteichoi acids. In Handbook of Lipid Research, vol. 6, Glycolipids, Phosphoglyco lipids and Sulfoglycolipids, pp. 123-234. Edited by M. Kates New York: Plenum Press.

Fischer, W., Koch, H. U. \& Haas, R. (1983). Improved preparatior of lipoteichoic acids. Eur J Biochem 133, 523-530.

Ghanem, F. M., Ridpath, A. C., Moore, W. E. C. \& Moore, L. V. H (1991). Identification of Clostridium botulinum, Clostridium argenti nense, and related organisms by cellular fatty acid analysis. J Cli Microbiol 29, 1114-1124.

Goldfine, H. (1982). Lipids of procaryotes - structure and dis tribution. Curr Top Membr Transp 17, 1-43.

Goldfine, H. (1993). Phospholipid biosynthetic enzymes of butyric acid-producing clostridia. In Genetics and Molecular Biology of Anaerobes, pp. 349-357. Edited by M. Sebald. New York: Springer

Goldfine, H. \& Hagen, P-O. (1972). Bacterial plasmalogens. In Ethe, Lipids: Chemistry and Biology, pp. 329-350. Edited by F. Snyder New York: Academic Press.

Goldfine, H., Johnston, N. C. \& Bishop, D. G. (1982). Ethes phospholipid asymmetry in Clostridium butyricum. Biochem Biopby: Res Commun 108, 1502-1507.

Goldfine, H., Johnston, N. C. \& Knob, C. (1993). The non-specific phospholipase $C$ of Listeria monocytogenes: activity on phospholipids in Triton X-100 mixed micelles and in biological membranes. $j$ Bacteriol 175, 4298-4306.

Gottfried, E. L. \& Rapport, M. M. (1962). The biochemistry of plasmalogens. I. Isolation and characterization of phosphatidal choline, a pure native plasmalogen. J Biol Chem 237, 329-333.

Johnson, J. L. \& Francis, B. S. (1975). Taxonomy of the clostridia: ribosomal ribonucleic acid homologies among the species. $J$ Gen Microbiol 88, 229-244.

Johnston, N. C. \& Goldfine, H. (1983). Lipid composition in the classification of the butyric acid-producing clostridia. $J$ Gen Microbiol 129, 1075-1081.

Johnston, N. C. \& Goldfine, H. (1988). Isolation and characterization of a novel four chain phospholipid, the phosphatidylglycerol acetal of plasmenylethanolamine from Clostridium butyricum. Biochim Biophys Acta 961, 1-12.

Kates, M. (1986). Techniques of Lipidology. Isolation, Analysis and Identification of Lipids, pp. 327-329. Amsterdam: North-Holland Publishing Co.

Kates, M. (1990). Glyco-, phospho-, and sulfoglycoglycerolipids of bacteria. In Handbook of Lipid Research, vol. 6, Glycolipids, Phosphoglycolipids, and Sulfoglycolipids, pp. 1-122. Edited by M. Kates. New York: Plenum Press.

Koostra, W. L. \& Smith, P. F. (1969). D- and L-alanylphosphatidylglycerols from Mycoplasma laidlawii, strain B. Biochemistry 8, 4794-4806. 
Kunst, A., Draeger, B. \& Ziegenhorn, J. (1984). D-Glucose. In Methods of Enzymatic Analysis, vol. VI, pp. 163-172. Edited by H. U. Bergmeyer, J. Bergmeyer \& M. Grassl. Weinheim/Deerfield Beach, FL/Basel: Verlag Chemie.

Laine, R. A. \& Renkonen, O. (1975). Analysis of anomeric configurations in glyceroglycolipids and glycosphingolipids by chromium trioxide oxidation. J Lipid Res 16, 102-105.

Lechevalier, H. \& Lechevalier, M. P. (1988). Chemotaxonomic use of lipids - an overview. In Microbial Lipids, vol. 1, pp. 869-902. Edited by C. Ratledge \& S. G. Wilkinson. London: Academic Press.

Lindberg, B. (1972). Methylation analysis of polysaccharides. Methods Enzymol 48, 178-195.

MacDonald, D. L. \& Goldfine, H. (1990). Phosphatidylglycerol acetal of plasmenylethanolamine as an intermediate in ether lipid formation in Clostridium butyricum. Biochem Cell Biol 68, 225-230.

Nakano, M. \& Fischer, W. (1977). The glycolipids of Lactobacillus casei DSM 20021. Hoppe Seyler's Z Physiol Chem 358, 1439-1453.

Nägele, U., Wahlefeld, A.W. \& Ziegenhorn, J. (1985). Triglycerides. In Methods of Enzymatic Analysis, vol. VIII, pp. 2-12. Edited by H. U. Bergmeyer, J. Bergmeyer \& M. Grassl. Weinheim: Verlag Chemie.

O'Leary, W. M. \& Wilkinson, S. G. (1988). Gram-positive bacteria. In Micrabial Lipids, vol. 1, pp. 117-201. Edited by C. Ratledge \& S. G. Wilkinson. London: Academic Press.

Ono, Y. \& White, D. C. (1970). Cardiolipin-specific phospholipase $\mathrm{D}$ activity in Haemophilus parainfuenzae. J Bacteriol 103, 111-115.

Rahn, C. H. \& Schlenk, H. (1973). Detection of aldehydes with 4amino-5-hydrazino-1,2,4-triazole-3-thiol as spray reagent. Lipids $\mathbf{8}$, 612-616.

Rogers, M. J., Simmons, J., Walker, R. T., Weisburg, W. G., Woese, C. R., Tanner, R. S., Robinson, I. M., Stahl, D. A., Olsen, G., Leach, R. H. \& Maniloff, J. (1985). Construction of the mycoplasma evolutionary tree from $5 \mathrm{~S}$ rRNA sequence data. Proc Natl Acad $S_{c i}$ US A 82, 1160-1164.
Shaw, N., Smith, P. F. \& Koostra, W. L. (1968). The lipid composition of Mycoplasma laidlawii strain B. Biochem J 107, 329-333.

Shaw, N., Smith, P. F. \& Verheij, H. M. (1972). The structure of a glycerylphosphoryldiglucosyl diglyceride from the lipids of Acholeplasma laidlawii strain B. Biocbem J 129, 167-173.

Short, S. A., White, D. C. \& Aleem, M. I. H. (1969). Phospholipid metabolism in Ferrabacillus ferrooxidans. J Bacteriol 99, 142-150.

Smith, P. F. (1972). A phosphatidyl diglucosyl diglyceride from Acholeplasma laidlawii B. Biochim Biophys Acta 280, 375-382.

Smith, P. F. (1977). Homogeneity of lipopolysaccharides from Acholeplasma. J Bacteriol 130, 393-398.

Stackebrandt, E. \& Woese, C. R. (1981). The evolution of prokaryotes. In Molecular and Cellular Aspects of Microbial Evolution, pp. 1-31. Edited by M. J. Carlile, J. F. Collins \& B. E. B. Moseley. Cambridge: Cambridge University Press.

Vioque, E. (1984). Spray reagents for thin-layer chromatography (TLC) and paper chromatography (PC). In Handbook of Cbromatograpby, Lipids, vol. I, pp. 309-317. Edited by H. K. Mangold. Boca Raton, FL: CRC Press.

Viswanathan, C. V., Phillips, F. \& Lundberg, W. O. (1968). Twodimensional reaction thin-layer chromatography in the analysis of phosphatide plasmalogens. J Chromatogr 35, 66-71.

Wieslander, Å. \& Rilfors, L. (1977). Qualitative and quantitative variations of membrane lipid species in Acholeplasma laidlawii A. Biochim Biophys Acta 466, 336-346.

Wittenberg, J. B., Korey, S. R. \& Swenson, F. H. (1956). The determination of higher fatty aldehydes in tissues. $J$ Biol Chem 219 , 39-47.

Yamamoto, A. \& Rouser, G. (1970). Spectrophotometric determination of molar amounts of glycosphingolipids and ceramide by hydrolysis and reaction with trinitrobenzenesulfonic acid. Lipids $\mathbf{5}$, 442- 444.

Received 23 June 1993; revised 22 September 1993; accepted 28 September 1993. 